\title{
Studies on Mustard (Brassica juncea L.) based Intercropping Systems under Rainfed Condition
}

\author{
Sumit Raj* and S.K. Uttam \\ Department of Soil Conservation and Water Management, C.S. Azad University of Agriculture \\ and Technology, Kanpur (U.P.), India \\ *Corresponding author
}

\section{A B S T R A C T}

\section{Keywords}

Rainfed, Moisture content, Moisture extraction pattern,

Water use

efficiency, Land equivalent ratio, Additive series, Replacement series

Article Info

Accepted:

15 October 2020

Available Online:

10 November 2020
A field experiment was conducted during the rabi seasons of 2016-17 and 2017-18 at Kanpur to study the relative productivity and profitability of intercropping systems on light textured soil under rainfed condition. On the basis of 2 years data revealed that intercropping system, namely, mustard + chickpea additive sowing found superior as compared to other treatments in productivity, water use efficiency, net return and benefit: cost ratio. However, soil moisture content up to one metre depth was recorded maximum under sole lentil at almost all the plant growth stages during course of investigation. Dust mulching at 25 DAS gave higher mustard equivalent seed yield and land equivalent ratio over without dust mulch treatment. The higher water use efficiency and net return were also recorded when dust mulching practice was adopted.

\section{Introduction}

With the rapid growth of population in recent times, pressure on land increased and the size of holdings considerably decreased in spite of extending the cultivation to marginal and submarginal lands. The problem of preventing the crop failure becomes more acute in dry tracts and calls for immediate attention of its solution in every possible way. The need for scientific approach towards farming in rainfed areas was felt with the increasing realization that instead of waiting and hoping for adequate rain, the modern concept is to make the cropping strategy, so flexible that it can be suitably changed even at short notice to suit the pattern of rainfall available. To meet the water requirement of the crop plants it is essential to adopt such management practices which may help in retention of moisture in soil at least till the crop needs. Every effort should be made to increase amount of water 
available to the crop for production, and reduce to the minimum loss of water due to evaporation and transpiration. Reducing water losses due to evaporation from the soil can result from mulching of soil and indirectly management practices such as weed control, planting density and patterns. Dust mulch is an indigenous practice, adopted for soil and water conservation, weed control and to facilitate better soil physical conditions. The present study on intercropping of mustard with chickpea and lentil in different row proportions is aimed to find out most productive and remunerative system for rainfed lands of central plain zone of Uttar Pradesh having light textured eroded lands suffering with twin problem on low fertility and moisture scarcity.

\section{Materials and Methods}

A field experiment was conducted during the rabi seasons of 2016-17 and 2017-18 at Students Instructional Farm of C.S. Azad University of Agriculture and Technology, Kanpur. Soil of the experimental field was sandy loam having $0.33 \%$ organic carbon, $0.032 \%$ total-N, $168.2 \mathrm{~kg} \mathrm{ha}^{-1}$ available-N, $17.2 \mathrm{~kg} \mathrm{ha}^{-1} \mathrm{P}_{2} \mathrm{O}_{5}$ and $169.5 \mathrm{~kg} \mathrm{ha}^{-1}$ available $\mathrm{K}_{2} \mathrm{O}$. It was slightly alkaline with $7.9 \mathrm{pH}$ and $0.47 \mathrm{dSm}^{-1}$ electrical conductivity. The field capacity, wilting point and bulk density of surface soil $(0-15 \mathrm{~cm})$ were $19.8 \%, 6.2 \%$ and $1.36 \mathrm{Mg} \mathrm{m}^{-3}$, respectively. The treatments consisted of 9 cropping systems i.e., (i) sole mustard, $50 \mathrm{~cm}$ apart (ii) sole chickpea, $30 \mathrm{~cm}$ apart (iii) sole lentil, $30 \mathrm{~cm}$ apart (iv) mustard + chickpea $(1+1)$, additive series (v) mustard + chickpea (3:1), replacement series (vi) mustard + chickpea $(3: 2)$, replacement series (vii) mustard + lentil $(1+1)$, additive series(viii) mustard + lentil (3:1), replacement series, mustard + lentil (3:2) replacement series and 2 mulches i.e. (i) without dust mulch (ii) with dust mulch created by weeding and hoeing at 25 DAS were tested in the experiment. The treatments were replicated thrice in a Split plot design, keeping cropping systems in main plots and mulch practices in sub-plots. The base crop was taken mustard, while chickpea and lentil were tried as intercrops. Mustard variety 'Pitambari', chickpea variety 'Awrodhi' and lentil variety ' $\mathrm{K}-75$ ' were sown in the experiment. An uniform dose of $20 \mathrm{~kg} \mathrm{~N}+40$ $\mathrm{kg} \mathrm{P}_{2} \mathrm{O}_{5} \mathrm{ha}^{-1}$ in sole chickpea and lentil as well as $60 \mathrm{~kg} \mathrm{~N}+30 \mathrm{~kg} \mathrm{P}_{2} \mathrm{O}_{5}+30 \mathrm{~kg} \mathrm{~K}_{2} \mathrm{O}$ $\mathrm{ha}^{-1}$ in sole mustard crop. In intercroppings, each crop was fertilized as same rates but on the basis of actual area sown under component crops. The fertilizers were applied row-wise. Seed for sowing was used @ 5 kg ha $^{-1}$ of mustard, $80 \mathrm{~kg} \mathrm{ha}^{-1}$ of chickpea and 50 $\mathrm{kg} \mathrm{ha}{ }^{-1}$ of lentil in sole cropping. Recommended package of cultural operations was followed. The crops were sown on October 30 and November 01 in first and second year, respectively. Sowing was followed by light planking. The lentil crop was harvested on March 07 and 05, mustard crop on March 10 and 07 as well as chickpea crop on March 24 and 20 during 2016-17 and 2017-18, respectively. At sowing time, available soil moisture in $100 \mathrm{~cm}$ soil profile was 270.3 and $275.6 \mathrm{~mm}$ during 2016-17 and2017-18, respectively. Total rainfall during crop period was 28.80 and $5.40 \mathrm{~mm}$ during first and second year, respectively.

Soil moisture of the sample collected from 0$25,25-50,50-75$ and 75-100 $\mathrm{cm}$ depth was determined thermo-gravimetrically from each treatment in one replication at different stages of crop growth. The amount of moisture used by the crop under different treatments was computed by summing up the values of soil moisture depletion from the profile during entire crop season. Water use efficiency of the crop was calculated by the method described by Viets (1962). Moisture extraction pattern was determined layer wise during the crop season. The total soil moisture extraction 
from the root-zone $(0-100 \mathrm{~cm})$ was calculated by summing of moisture use for all the layers. Moisture depletion from each layer was then expressed as percentage of soil moisture depletion from root-zone. Mustard equivalent seed yield was worked out by converting the yield of chickpea and lentil into mustard yield on the basis of prevailing market price. The economics of various treatments were computed on the basis of prevailing market price of produce and agro-inputs.

\section{Results and Discussion}

\section{Soil moisture content}

Soil moisture content up to one metre depth was recorded maximum under sole lentil at almost all the plant growth stages during course of investigation (Table-1). Proper crop cover and low water requirement of lentil crop reduced evaporation loss, thus left more moisture in soil.

The plots of additive intercropping contained minimum soil moisture might be attributed to highest plant density per unit area which required more soil moisture for growth and development of crop plants. Higher soil profile moisture content was observed under dust mulching plot over without dust mulching plot at different stages of crop growth during both the years.

Relatively higher moisture in case of dust mulching plot may be attributed to helps arrest rainfall at the site of occurrence and provide more opportunity and time to rainwater to go into the soil and control of weeds and evaporational losses of moisture. Better moisture conservation under dust mulching plots have been reported by a number of research workers, (Katiyar et al., 2003; Chaudhary et al., 2008 and Awal and Farzana, 2011) which lend credence to these results.
Total water use (TWU) and Water use efficiency (WUE)

TWU was estimated higher in mustard + chickpea $(1+1)$ additive intercropping than other cropping systems during both the experimental years (Table-2). It might be attributed to highest plant density per unit area which required more soil moisture for growth and development of crop plants. Mustard + chickpea $(1+1)$ additive intercropping also recorded higher WUE might be attributed to higher mustard equivalent seed yield. These results are similar with the findings of Rajvanshi (2013). Dust mulching practice of moisture conservation recorded lower TWU and higher WUE as compared to without dust mulch treatment during both the years. Higher WUE recorded by crops grown under dust mulching plots might have been due to eradication of weeds, more pulverize surface soil resulting less evaporation and transpiration loss of water through weeds which in turn made it possible to utilize moisture by the crops more efficiently over without dust mulch practice. Those observations corroborate with the findings of Yadav et al., (2011) and RajKumar et al., (2018).

\section{Moisture extraction pattern (MEP)}

Different cropping systems and mulch practices could not bring about any large difference in soil MEP during both the years (Table-2). The surface layer of $0-25 \mathrm{~cm}$ exhibited soil MEP which was to extent of 41.13 and $40.70 \%$ followed by $25-50 \mathrm{~cm}$ which showed 29.43 and $29.23 \%$ extraction while lowest was observed the layer 75-100 $\mathrm{cm}$ (10.45 and 10.80\%) during 2016-17 and 2017-18, respectively. In $0-25 \mathrm{~cm}$ soil depth, sufficient moisture was conserved, thus more horizontal development of roots are finally more moisture extracted from surface layer. 
Table.1 Soil moisture content up to one metre depth $(\mathrm{mm})$ at different intervals as influenced by cropping systems and mulches

\begin{tabular}{|c|c|c|c|c|c|c|c|c|c|c|c|c|}
\hline \multirow{2}{*}{ Treatment } & \multicolumn{6}{|c|}{ 2016-17 } & \multicolumn{6}{|c|}{ 2017-18 } \\
\hline & $\begin{array}{l}\text { Sowing } \\
\text { time }\end{array}$ & 30DAS & 60DAS & 90DAS & 120DAS & $\begin{array}{c}\text { At } \\
\text { harvest }\end{array}$ & $\begin{array}{l}\text { Sowing } \\
\text { time }\end{array}$ & 30DAS & 60DAS & 90DAS & 120DAS & $\begin{array}{c}\text { At } \\
\text { harvest }\end{array}$ \\
\hline \multicolumn{13}{|c|}{ Cropping systems } \\
\hline Sole mustard & 270.3 & 224.7 & 158.6 & 162.1 & 106.5 & 90.8 & 275.6 & 225.6 & 157.3 & 146.2 & 104.9 & 93.6 \\
\hline Sole chickpea & 270.3 & 224.8 & 174.3 & 196.8 & 163.5 & 146.4 & 275.6 & 226.3 & 175.2 & 182.1 & 158.8 & 143.0 \\
\hline Sole lentil & 270.3 & 225.0 & 174.7 & 197.8 & 165.2 & 154.2 & 275.6 & 226.4 & 179.1 & 188.1 & 167.4 & 159.2 \\
\hline $\begin{array}{l}M+C P(1+1)- \\
\text { add. }\end{array}$ & 270.3 & 224.7 & 155.1 & 155.4 & 98.6 & 81.3 & 275.6 & 225.7 & 153.0 & 136.1 & 90.3 & 80.7 \\
\hline $\begin{array}{l}\mathrm{M}+\mathrm{CP}(3: 1)- \\
\text { repl. }\end{array}$ & 270.3 & 224.7 & 167.3 & 179.3 & 132.0 & 115.8 & 275.6 & 225.9 & 168.6 & 163.9 & 128.5 & 113.8 \\
\hline $\begin{array}{l}\mathrm{M}+\mathrm{CP}(3: 2)- \\
\text { repl. }\end{array}$ & 270.3 & 224.8 & 166.0 & 176.9 & 128.9 & 111.6 & 275.6 & 225.8 & 167.8 & 162.6 & 126.3 & 109.8 \\
\hline$M+L(1+1)-$ add & 270.3 & 224.7 & 156.0 & 157.3 & 101.2 & 85.6 & 275.6 & 225.5 & 154.9 & 141.3 & 97.3 & 86.6 \\
\hline M + L (3:1)-repl. & 270.3 & 225.0 & 167.3 & 179.2 & 131.9 & 117.5 & 275.6 & 226.1 & 169.8 & 165.8 & 130.8 & 115.9 \\
\hline M + L (3:2)-repl. & 270.3 & 224.9 & 166.9 & 178.1 & 130.4 & 115.3 & 275.6 & 225.9 & 168.4 & 163.5 & 127.9 & 112.5 \\
\hline \multicolumn{13}{|l|}{ Mulches } \\
\hline $\begin{array}{l}\text { Without dust } \\
\text { mulch }\end{array}$ & 270.3 & 224.7 & 164.4 & 174.6 & 126.7 & 111.0 & 275.6 & 225.6 & 164.8 & 159.2 & 123.6 & 110.4 \\
\hline With dust mulch & 270.3 & 224.9 & 165.9 & 177.2 & 130.6 & 115.3 & 275.6 & 226.2 & 167.2 & 162.8 & 128.0 & 115.2 \\
\hline
\end{tabular}


Table.2 Total water use, water use efficiency and soil moisture extraction pattern as influenced by cropping systems and mulches

\begin{tabular}{|c|c|c|c|c|c|c|c|c|c|c|c|c|}
\hline \multirow{4}{*}{ Treatment } & \multirow{3}{*}{\multicolumn{2}{|c|}{$\begin{array}{c}\text { Total water use } \\
\text { (mm) }\end{array}$}} & \multirow{3}{*}{\multicolumn{2}{|c|}{$\begin{array}{c}\text { Water use efficiency } \\
\left(\mathrm{kg} \mathrm{seed} \mathrm{ha}^{-1} \mathrm{~mm}^{-1} \text { of }\right. \\
\text { water) }\end{array}$}} & \multicolumn{8}{|c|}{ Moisture extraction pattern (\%) } \\
\hline & & & & & \multicolumn{8}{|c|}{ Soil depth $(\mathrm{cm})$} \\
\hline & & & & & $0-25$ & $25-50$ & $50-75$ & $75-100$ & $0-25$ & $25-50$ & $50-75$ & $75-100$ \\
\hline & 2016-17 & 2017-18 & 2016-17 & $2017-18$ & \multicolumn{4}{|c|}{ 206-17 } & \multicolumn{4}{|c|}{$2017-18$} \\
\hline \multicolumn{13}{|c|}{ Cropping systems } \\
\hline Sole mustard & 268.3 & 247.4 & 6.20 & 6.28 & 39.22 & 30.20 & 19.95 & 10.63 & 38.70 & 29.82 & 20.16 & 11.32 \\
\hline Sole chickpea & 212.8 & 198.0 & 8.75 & 8.78 & 42.18 & 28.41 & 17.90 & 11.51 & 41.86 & 28.00 & 18.17 & 11.97 \\
\hline Sole lentil & 204.9 & 183.3 & 5.29 & 5.33 & 43.20 & 27.29 & 18.12 & 11.39 & 42.94 & 27.02 & 18.46 & 11.58 \\
\hline $\begin{array}{l}M+C P(1+1)- \\
\text { add. }\end{array}$ & 277.8 & 260.3 & 8.87 & 8.90 & 40.15 & 30.18 & 19.23 & 10.44 & 39.84 & 29.88 & 19.66 & 10.62 \\
\hline $\begin{array}{l}\mathrm{M}+\mathrm{CP}(3: 1)- \\
\text { repl. }\end{array}$ & 243.3 & 227.2 & 7.26 & 7.35 & 40.69 & 29.39 & 19.21 & 10.71 & 40.19 & 29.69 & 19.43 & 10.69 \\
\hline $\begin{array}{l}\mathrm{M}+\mathrm{CP}(3: 2)- \\
\text { repl. }\end{array}$ & 247.7 & 231.2 & 7.50 & 7.66 & 40.88 & 29.60 & 19.00 & 10.52 & 40.28 & 29.80 & 19.32 & 10.60 \\
\hline $\begin{array}{l}M+L(1+1)- \\
\text { add. }\end{array}$ & 273.5 & 254.4 & 7.76 & 7.81 & 40.79 & 29.72 & 19.10 & 10.39 & 40.17 & 29.24 & 19.43 & 11.16 \\
\hline $\begin{array}{l}M+L(3: 1)- \\
\text { repl. }\end{array}$ & 241.6 & 225.1 & 6.55 & 6.58 & 41.49 & 29.99 & 19.29 & 9.23 & 41.06 & 29.71 & 19.51 & 9.72 \\
\hline $\begin{array}{l}M+L(3: 2)- \\
\text { repl. }\end{array}$ & 243.8 & 228.5 & 6.59 & 6.66 & 41.58 & 30.10 & 19.08 & 9.24 & 41.25 & 29.92 & 19.30 & 9.53 \\
\hline \multicolumn{13}{|l|}{ Mulches } \\
\hline $\begin{array}{l}\text { Without dust } \\
\text { mulch }\end{array}$ & 248.1 & 230.6 & 6.57 & 6.51 & 40.92 & 29.31 & 18.96 & 10.81 & 40.48 & 28.95 & 19.46 & 11.11 \\
\hline $\begin{array}{l}\text { With dust } \\
\text { mulch }\end{array}$ & 243.8 & 226.1 & 7.83 & 8.02 & 41.34 & 29.55 & 19.02 & 10.09 & 40.92 & 29.51 & 19.08 & 10.49 \\
\hline
\end{tabular}


Table.3 Seed yield of component crops, mustard equivalent seed yield, land equivalent ratio, net return and benefit : cost ratio as influenced by cropping systems and mulches

\begin{tabular}{|c|c|c|c|c|c|c|c|c|c|c|}
\hline \multirow[t]{2}{*}{ Treatment } & \multicolumn{2}{|c|}{$\begin{array}{l}\text { Seed yield of component } \\
\text { crops }\left(\mathrm{q} \mathrm{ha}^{-1}\right)\end{array}$} & \multicolumn{2}{|c|}{$\begin{array}{c}\text { Mustard equivalent } \\
\text { seed yield } \\
\left(q \mathrm{ha}^{-1}\right)\end{array}$} & \multicolumn{2}{|c|}{ Land equivalent ratio } & \multicolumn{2}{|c|}{ Net return $\left(\right.$ Rsha $\left.^{-1}\right)$} & \multicolumn{2}{|c|}{$\begin{array}{l}\text { Benefit : Cost } \\
\text { ratio }\end{array}$} \\
\hline & $\mathrm{Y}_{1}$ & $\mathrm{Y}_{2}$ & $\mathrm{Y}_{1}$ & $\mathrm{Y}_{2}$ & $Y_{1}$ & $\mathrm{Y}_{2}$ & $Y_{1}$ & $\mathrm{Y}_{2}$ & $\mathrm{Y}_{1}$ & $\mathrm{Y}_{2}$ \\
\hline \multicolumn{11}{|l|}{ Cropping systems } \\
\hline Sole mustard & 16.64 & 15.54 & 16.64 & 15.54 & 1.00 & 1.00 & 32085 & 32746 & 1.96 & 1.96 \\
\hline Sole chickpea & 17.23 & 15.79 & 18.62 & 17.37 & 1.00 & 1.00 & 37921 & 34792 & 2.06 & 1.86 \\
\hline Sole lentil & 10.15 & 9.20 & 10.84 & 9.77 & 1.00 & 1.00 & 10624 & 3948 & 1.33 & 1.10 \\
\hline$M+C P(1+1)-$ add & $17.82(6.31)$ & $16.89(5.70)$ & 24.64 & 23.16 & 1.43 & 1.45 & 53404 & 54557 & 2.22 & 2.21 \\
\hline M + CP (3:1)-repl. & $13.34(4.00)$ & $12.63(3.67)$ & 17.66 & 16.67 & 1.03 & 1.04 & 34110 & 34608 & 1.96 & 1.93 \\
\hline M + CP (3:2)-repl. & $13.42(4.76)$ & $12.78(4.46)$ & 18.56 & 17.68 & 1.08 & 1.11 & 37112 & 37441 & 2.02 & 1.96 \\
\hline$M+L(1+1)-a d d$ & $17.58(3.40)$ & $16.54(3.13)$ & 21.21 & 19.87 & 1.38 & 1.41 & 43527 & 41955 & 2.09 & 1.97 \\
\hline M + L (3:1)-repl. & $13.25(2.42)$ & $12.43(2.24)$ & 15.83 & 14.81 & 1.03 & 1.04 & 27741 & 27105 & 1.80 & 1.74 \\
\hline M + L (3:2)-repl. & $13.25(2.66)$ & $12.54(2.51)$ & 16.07 & 15.20 & 1.05 & 1.08 & 28281 & 27508 & 1.81 & 1.72 \\
\hline SE (d) & - & - & 0.86 & 0.80 & 0.06 & 0.06 & - & - & - & - \\
\hline $\mathrm{CD}(\mathrm{P}=0.05)$ & - & - & 1.82 & 1.70 & 0.13 & 0.13 & - & - & - & - \\
\hline \multicolumn{11}{|l|}{ Mulches } \\
\hline With dust mulch & $15.86(4.30)$ & $15.07(4.05)$ & 19.19 & 18.24 & 1.12 & 1.14 & 35778 & 35197 & 1.89 & 1.81 \\
\hline SE (d) & - & - & 0.46 & 0.44 & 0.05 & 0.06 & - & - & - & - \\
\hline $\mathrm{CD}(\mathrm{P}=0.05)$ & - & - & 1.00 & 0.92 & NS & NS & - & - & - & - \\
\hline \multicolumn{11}{|c|}{ Note: Figures in parentheses indicate yield of intercrops. } \\
\hline $\begin{array}{l}\text { Minimum support } \\
\text { price: }\end{array}$ & $2016-17$ & $2017-18$ & & & & & & & & \\
\hline Mustard seed@ Rs & $3700 q^{-1}$ & $4000 q^{-1}$ & & & & & & & & \\
\hline Chickpea seed@Rs & $4000 q^{-1}$ & $4400 q^{-1}$ & & & & & & & & \\
\hline Lentil seed@ Rs & $3950 q^{-1}$ & $4250 q^{-1}$ & & & & & & & & \\
\hline
\end{tabular}


Similar results have also been reported by Dhiman Ray et al., (2003) and Sarkar and Pal (2005).

\section{Seed yield of component crops}

Seed yield of both the intercropped crops reduced in association with mustard as compared to their sole crops (Table-3). Corresponding yield reduction was more under intercropping of mustard with chickpea and lentil additive series and less under intercropping of mustard with chickpea and lentil in 3:2 row ratio in both the years. All the cropping systems exhibited higher seed yield under dust mulch practice than without dust mulch plot in both the years of experimentation.

\section{Mustard Equivalent Seed Yield (MESY)}

MESY was recorded significantly highest under mustard +chickpea $(1+1)$ additive intercropping followed by mustard + lentil $(1+1)$ additive intercropping while sole lentil gave significantly lowest during 2016-17 and 2017-18 (Table-3). The maximum seed yield being recorded with mustard + chickpea $(1+1)$ additive sowing may be attributed to its more adoptability scarce moisture condition by developing root system in the deeper soil layer as a result the maximum bifurcation of branches and higher seed production of both crops. These results are in accordance to the findings of Rajvanshi (2013), Lal et al., (2015) and Kour et al., (2015). Out of two mulch practices, dust mulch practice recorded significantly higher MESY as compared to without dust mulch treatment during both the years. The higher seed yield observed with dust mulching plot might have been due to sufficient moisture conserved in soil which remained for longer period, provided its life cycle successfully. These results are in accordance with that of Katiyar et al., (2015) and Chavada et al., (2017).

\section{Land equivalent ratio (LER)}

LER was found highest in mustard + chickpea $(1+1)$ additive intercropping followed by mustard + lentil $(1+1)$ additive sowing during both the years (Table-3). It might be attributed to full yield of mustard and additional yield of intercrop. However, all intercropping systems improve LER over sole croppings during 2016-17 and 2017-18. It might be attributed to the fact that seed yield of component crops in intercropping was higher in proportion to area sown under component crops because of better utilization of available resources. These results are conformity to the findings of Rajvanshi (2013) and Kour et al., (2015). Dust mulch practice produce higher LER over without dust mulch treatment during both the years. Better utilization of land and growth resources by crops in dust mulch practice.

\section{Economics}

Net return and B:C ratio were highest under additive intercropping of mustard + chickpea $(1+1)$ followed by additive intercropping of mustard + lentil $(1+1)$. It might be attributed to higher mustard equivalent seed yield in these intercroppings. These findings are in accordance with the results of Rajvanshi (2013) and Kour et al., (2015). As a practice of moisture conservation, dust mulching exhibited higher net return as compared to without dust mulch treatment. However, this treatment was failed to exhibit superiority in $\mathrm{B}: \mathrm{C}$ ratio over without dust mulching due to additional cost of dust much formation.

\section{References}

Awal, M.A. and Farzana, S. (2011). Microclimatic alteration and productivity of mustard crop as induced by indigenous mulches. International Journal of Agricultural Research, 6(12): 819-829.

Chaudhary, H.P.; Yogesh Singh and Uttam , 
S.K. (2008), Moisture use, root development and yield of mustard (Brassica juncea L.) in relation to nutrient management and moisture conservation practices under rainfed conditions. Journal of Soil and Water Conservation, 7(2): 23-29.

Chavada, J.N.; Patel, C.K.; Patel, S.B.; Panchal, P.P. andPatel, G.N. (2017). Weed management in chickpea (Cicer arietinum L.) under North Gujarat conditions. International Journal of Science, Environment and Technology, 6(3): 20172018.

Dhiman Ray; Bandyopadhyay, P.; Datta, D. and Jana, P.K. (2003). Studies on growth, water use efficiency and crop coefficient of mustard (Brassica juncea L.) under limited irrigation. Research on Crops, 4 (2): 178-181.

Katiyar, A.K.; Chaudhary, H.P. and Uttam, S.K. (2003).Effect of mustard intercropping in barley under various fertility levels with and without interculture under rainfed condition. Indian Journal of Soil Conservation, 31(1) :35-40.

Katiyar, A.K.; Uttam, S.K.; Awasthi, U.D. and Rajput, P.K.(2015). Effect of moisture conservation practices on mustard based intercropping system with lentil under rainfed condition. Abstract: National Seminar on Managing Crop Productivity for Food Security in Changing Climate Scenario, held at Janta College, Bekewar, Etawah (U.P.) from March 28-29 pp. 119.

Kour, R.; Sharma, B.C.; Anil Kumar and Sharma, N. (2015). Yield analysis of chickpea (Cicer arietinum) + Indian mustard (Brassica juncea) intercropping system through computation of intercropping indices. Indian Journal of
Agronomy, 60(3): 381-385.

Lal, B.; Rana, K.S.; Gautam, P.; Rana, D.S.; Shivay, Y.S.; Meena, B.P.; Meena, R.K. and Singh, P. (2015). Ethiopian mustardchickpea intercropping system is a viable option for yield advantage in dryland condition of North India-Part-I. Proc. National Academy of Sciences, pp. 518527

Raj Kumar; Munish Kumar; Sarvesh Kumar; Mahak Singh and Mangal Prasad (2018). Quality parameters, moisture studies and economics of mustard 'Basanti' under different dates of sowing and moisture conservation practices under rainfed ecosystem of central Uttar Pradesh. Journal of Pharmacognosy and Phytochemistry, 7 (2):1051-1055.

Rajvanshi, J.K. (2013). Production potential of mustard (Brassica juncea L.) based intercropping systems under rainfed condition. M.Sc. (Ag.) Thesis, Department of Soil Conservation and Water Management, C.S. Azad University of Agriculture and Technology, Kanpur.

Sarkar, B. and Pal, A.K. (2005). Water use and yield of rapeseed (Brassica campestris) and lentil (Lens culinaris) grown as sole crop and as interecrop. Journal of Interacademicia, 9 (1): 10-15.

Viets, F.G. (1962). Fertilizers and efficient use of water. Advances in Agronomy, 14: 223261.

Yadav, P.N.; Uttam, S.K.; Singh, R.P. and Kaushal Kumar (2011). Effect of fertilizer and moisture conservation on productivity, economics and water use efficiency of rainfed mustard (Brassica juncea). Current Advances in Agricultural Sciences, 3(2): 108-111.

\section{How to cite this article:}

Sumit Raj and Uttam, S.K. 2020. Studies on Mustard (Brassica juncea L.) based Intercropping Systems under Rainfed Condition. Int.J.Curr.Microbiol.App.Sci. 9(11): 1826-1833. doi: https://doi.org/10.20546/ijcmas.2020.911.216 